J-SANAK: Jurnal Kajian Anak

(p-ISSN: 2686-5343 |e-ISSN: 2715-7989)

Vol. (2)(02), (Januari-Juni)(2021), (Halaman)(76-88)

DOI: https://doi.org/10.24127/j-sanak.v2i02.816

\title{
PENGEMBANGAN KREATIVITAS ANAK MELALUI KEGIATANMEMBENTUK TANAH LIAT DI TAMAN KANAK-KANAK
}

\author{
Sri Desi ${ }^{1}$ \\ Universitas Negeri Padang \\ sridesi181@gmail.com \\ Indra Jaya ${ }^{2}$ \\ Universitas Negeri Padang \\ indrajaya.pgpaudfipunp@gmail.com
}

\begin{abstract}
ABSTRAK
Pendidikan anak usia dini adalah suatu upaya pembinaan yan ditujukan bagi anak sejak lahir sampai usia enam tahun yang dilakukan melalui pemberian rangsangan pendidikan, yang bertujuan untuk membantu pertumbuhan dan perkembangan jasmani dan rohani anak agar memiliki kesiapan dalam memasuki pendidikan selanjutnya. Perkembangan kreativitas adalah kemampuan seseorang untuk menghasilkan sesuatu yang baru dan kombinasi baru, baik berupa gagasan maupun karya nyata yang relatif berbeda dengan apa yang telah ada sebelumnya. Peningkatan kreativitas anak dapat dilakukan dengan kegiatan membentuk menggunakan tanah liat. Peneitian ini bertujuan untuk mendiskripsikan perkembangan kreativitas anak melalui kegiatan membentuk tanah liat di taman kanak-kanak. Metode penelitian yang dilakukan adalah studi literatur. Adapun teknik pengumpulan data pada penelitian studi literatur adalah dengan cara mengumpulkan dan menelaah sumber-sumber yang relevan yang diambil dari jurnal, artikel, buku dan sumber lainnya yang terkait dengan masalah penelitian. Setelah mendapatkan kata yang diperlukan maka dilanjutkan dengan menganalisis data. Analisis data dilakukan dengan menghubungkan antara masalah dengan konsep teori yang relevan. Hasil penelitian yang diperoleh yaitu kegiatan membentuk tanah liat dapat mengembangkan perkembangan kreativitas pada anak, dapat memberikan kesempatan kepada anak untuk menciptakan karyanya sendiri, menstimulasi perkembangan anak, serta media yang digunakan sederhana dan mudah digunakan untuk anak bermain.
\end{abstract}

\section{Kata Kunci: Studi Literatur, Perkembangan Kreativitas, Membentuk Tanah} Liat

Received 27-04-2021; Received in revised form 19-06-2021; Accepted 03-07-2021.

\begin{abstract}
Early childhood education is a development effort aimed at children from birth to six years old through educational stimulation, which is aimed at helping children's physical and growth and development to have preparedness for further education. The development of creativity is a person's ability to produce something new or a new combination, either in the form of ideas or real work that is relatively different from what has been there before. To increase the children's creativity
\end{abstract}


J-SANAK: Jurnal Kajian Anak

(p-ISSN: 2686-5343 |e-ISSN: 2715-7989)

Vol. (2)(02), (Januari-Juni)(2021), (Halaman)(76-88)

DOI: https://doi.org/10.24127/j-sanak.v2i02.816

can be demostrated by shaping activities using clay. This study is aimed at quantifying the developmen of children's creativity through the clay forming in kindergarten. The method of research is the study of literature. As for yhe data collection taechniue in literature study is to collect and study relevant resources derived from the journals, articles, books and other sources associated with the research problem. After getting the required data then proceed with analyzing the data. The analysis is done by connecting the problem with relevant theoretical concepts. The results obtained are clay forming activities can develop the development of creativity in cjildren, can provide opportunities for children to create their own work, stimulate children's development, and the media used is simple and aesy to use for children's to play.

\section{Keywords: Literature Study, Creativity Develophment, Forming Clay}

\section{A. PENDAHULUAN}

Anak usia dini merupukan individu yang unik karena berada pada proses pertumbuhan dan perkembangan yang sangat pesat dan fundamental bagi kehidupan selanjutnya dan anak memilki dunia dan karekteristik tersendiri dan jauh berbeda dengan yang lainnya. Menurut Suryana (2013) menyatakan bahwa karakteristik anak usia dini yaitu, anak bersifat egosentri dan hanya mementingkan dirinya sendiri, memiliki rasa ingin tahu yang tinggi dengan rasa penasarannya terhadap apa yang dilihatnya, memiliki sifat yang unik, memiliki imajinasi dan fantasi yang tinggi dan memiliki daya konsentrasi yang pendek.

Pendidikan adalah suatu kegiatan yang universal dalam kehidupan manusia, setiap orang di dunia memerlukan pendidikan, yang mana pendidikan manusia belajar untuk mampu mencapai kemandirian serta mampu beradaptasi dengan lingkungan. Madyawati (2016) menyatakan bahwa pendidikan anak usia dini adalah suatu upaya pembinaan yang ditujukan kepada anak sejak lahir hingga usia 6 tahun dalam menumbuhkembangkan berbagai potensi anak yang dilakukan dengan memberikan rangsangan pendidikan dalam proses pertumbuhan dan perkembangan jasmani dan rohaninya, sehingga anak memiliki persiapan untuk hidup dan dapat menyesuaikan diri dengan lingkungan dan memiliki kesiapan untuk memasuki pendidikan yang lebih lanjut yang diselenggarakan pada jalur formal, nonformal dan informal.

Pendidikan anak usia dini bertujuan untuk merangsang dan membimbing anak dalam mengembangkan berbagai aspek perkembangan dan keterampilannya. Pendidikan anak usia dini sering disebut dengan istilah golden age atau masa keemasan yang merupakan masa peka, dimana pada masa ini perkembangan yang dimiliki anak akan dapat menentukan tahap perkembangan selanjutnya.

Proses pembelajarana anak usia dini di Taman Kanak-kanak menggunakan prinsip bermain sambil belajar, karena pada anak usia dini anak cenderung akan banyak mengahabiskan waktunya untuk bermain. Menurut Fadillah (2018) 
J-SANAK: Jurnal Kajian Anak

(p-ISSN: 2686-5343 |e-ISSN: 2715-7989)

Vol. (2)(02), (Januari-Juni)(2021), (Halaman)(76-88)

DOI: https://doi.org/10.24127/j-sanak.v2i02.816

menyatakan bahwa bermain dapat memberikan kesempatan kepada anak dalam mengembangkan kemampuan dirinya untuk berimajinasi dan bereksplorasi dan anak akan sering menunjukkan kreativitasnya dalam bermain. Melalui beriman dapat memberikan kesempatan kepada anak untuk melakukan berbagai aktivitas yang dapat mengembangkan kreativitas. Dengan bermain dapat memberikan suatu kesenangan bagi anak, karena dengan bermain dapat membantu pertumbuhan dan perkembangan pada anak.

Pendidikan anak usia dini mempunyai peranan yang sangat penting dalam menentukan pertumbuhan dan perkembangan anak. Salah satu aspek perkembangan yang penting untuk distimulasi oleh anak yaitu aspek perkembangan kreativitas. Kreativitas merupakan salah satu potensi yang dimiliki anak yang perlu dikembangkan sejak dini. Menurut Rachmawati dan Kurniati (2017) menyatakan bahwa kreativitas adalah kemampuan seseorang untuk menghasilkan atau menciptakan sesuatu yang baru baik berupa gagasan maupun karya nyata yang berbeda dengan apa yang sudah ada sebelumnya.

Penelitian Miranda (2018) menyatakan bahwa kreativitas anak didasari oleh keunikan, gagasan, imajinasi dan fantasi. Anak yang kreatif sensitif terhadap stimulasi dan cenderung memiliki kegiatan kegiatan dalam beraktivitas. Anak yang kreatif suka berimajinasi karena dengan berkreasi anak dapat mengaktualisasikan dan mengekspresikan dirinya, dengan memberikan kegiatan yang menarik kepada anak seperti aktivitas dalam membuat hasil karnya yang dapat membantu anak dalam mengembangkan imajinasi dan kreatifnya.

Penelitian Maulana dan Mayar (2019) menyatakan bahwa pengembangan kreativitas sangat penting dikembangkan sejak dini karena kreativitas sangat berpengaruh dalam kehidupan seseorang. Keberhasilan perkembangan kemampuan anak dapat dikembangkan melalui stimulasi yang diberikan oleh guru dan orangtua. Pengembangan kreativitas anak usia dini dapat distimulasi dengan memberikan kesempatan kepada anak dalam berbagai aktivitas kesehariannya. Diantaranya dengan memberikan kesempatan bagi pengembangan kreativitas anak malalui aktivitas seni. Pengembangan seni bertujuan agar anak mampu berimajinasi untuk menciptakan atau menghasilkan sesuatu berupa hasil karya yang bernilai kreatif.

Kreativitas seni yang tidak asing dilakukan di dalam kehidupan sehari-hari, khususnya bagi anak usia dini adalah dengan kegiatan membentuk menggunakan tanah liat. Membentuk merupakan kegiatan membuat karya seni rupa tiga dimensi dengan menggunakan bahan yang bersifat lunak seperti playdough, tanah liat, platisin dan bubuk kertas yang dikerjakan dengan berbagai cara seperti membutsir, memahat, mengukir dan juga mencetak yang dilakukan untuk membuat bentuk yang diinginkan ( Sulastianto, dkk. 2006)

Kegiatan membentuk sangat diperlukan untuk pengembangan anak secara menyeluruh. Kegiatan membentuk dapat dilakukan dengan mengamati benda tiga 
J-SANAK: Jurnal Kajian Anak

(p-ISSN: 2686-5343 |e-ISSN: 2715-7989)

Vol. (2)(02), (Januari-Juni)(2021), (Halaman)(76-88)

DOI: https://doi.org/10.24127/j-sanak.v2i02.816

dimensi, mencoba menirukan dan kemudian anak mengkreasikan dengan ide yang anak inginkan. Adapun manfaat membentuk menurut Pamadhi dan Sukardi (2018) yaittu, mengenalkan kepada anak benda alam yang terdapat dilingkungan sekitarnya, dapat mengambangkan fungsi otak kiri dan kanan serta rasa kepada anak, mengembangkan keterampilan anak dalam menumbuhkan kecakapan yang dapat digunakan untuk kebutuhan hidupnya.

Rahayu dan Khaironi (2019) menyatakan bahwa penggunaan media bahan alam tanah liat merupakan suatu media yang dapat meningkatkan imajinasi anak dalam mengembangkan kreativitasnya secara bebas. Kreativitas anak dapat terasah ketika anak mampu membuat berbagai macam bentuk dari tanah liat. Menurut Wahyuni (2019) menyatakan bahwa media tanah liat sangat baik diterapkan dalam proses pembelajaran, karena dengan media tanah liat anak dapat meningkatkan imajinasinya untuk berfikir secara bebas dalam mengembangkan kreatifnya.

Wahyuni (2019) menjelaskan bahwa tanah liat bertujuan untuk melatih anak dalam mengembangkan imajinasi dan kretaivitasnya dalam berkarya, dengan menjelaskan kepada anak bagaimana cara membentuk tanah liat sesuai dengan keinginan anak itu sendiri. Anak bermain tanah liat yang sudah terpilih dari hasil proses tahapan sehingga tidak membahayakan bagi anak. Menurut Maisarah, Mahmud dan Saugi (2020) menjelaskan bahwa manfaat tanah liat dapat meningkatkan dan mengembangkan kreativitas anak dalam mencipatakan sesuatu yang baru. Tanah liat merupakan bahan alam yang mudah dibentuk sehingga anak pun bebas dalam memanfaatkannya untuk membuat apa saja sesuai dengan imajinasinya sendiri.

Pengembangan kreativitas anak perlu adanya strategi yang digunakan. Menurut Sit, dkk. (2016) menjelaskan bahwa dalam pengembangan kreativitas anak menggunakan pendekatan $4 p$ yang terdiri dari pribadi, pedorong, proses dan produk. Pribadi yang kreatif akan melibatkan dirinya dalam proses yang kreatif dengan dorongan dan dukungan dari lingkungannya untuk menghasilkan suatu produk berupa hasil karya dengan menggunakan imajinasinya untuk melakukan sesuatu sesuai dengan khayalannya.

\section{B. METODOLOGI}

Jenis penelitian yang digunakan dalam penelitian ini adalah penelitian studi literatur yang menggunakan buku-buku dan literatur-literatur lainnya sebagi objek penelitian yang utama. Studi literatur sering disebut juga studi pustaka. Menurut Zed ( 2008) menyatakan bahwa studi pusataka adalah serangkaian kegiatan yang berkenaan dengan memanfaatkan sumber pustaka dalam metode pengumpulan data dengan membaca, mencatat serta mengolah bahan penelitian untuk memperoleh data tampa adanya keterlibatan peneliti di lapangan. 
J-SANAK: Jurnal Kajian Anak

(p-ISSN: 2686-5343 |e-ISSN: 2715-7989)

Vol. (2)(02), (Januari-Juni)(2021), (Halaman)(76-88)

DOI: https://doi.org/10.24127/j-sanak.v2i02.816

Langkah-langkah dalam penelitian kepustakaan menurut Zed (2008) yaitu, menyiapkan alat perlengkapan, menyusun bibliografi kerja, mengatur waktu serta membaca dan membuat catatan penelitan. Adapun teknik pengumpulan data pada penelitian ini adalah dengan cara mencari dan mengumpulkan sumber-sumber data yang relevan terkait dengan topik penelitian yang diambil dari buku, jurnal dan skripsi.

Jenis data yang digunakan dala penelitian ini adalah jenis data skunder. Menurut Zed (2008) menjelaskan bahwa data sekunder adalah jenis data yang diperoleh peneliti dari tulisan orang lain sesuai dengan topik penelitian yang akan dilakukan peneliti dengan membaca, mencatat serta mengolah bahan penelitian untuk memperoleh data, tampa harus melibatkan peneliti untuk melakukan penelitian langsung kelapangan. Teknik analisis data berupa analisi is yang merupakan pembahasan yang bersifat mendalam terhadap isi dari suatu informasi tercetak maupun informasi tidak tercetak yang bersumber dari internet dengan menganalisis buku, jurnal atau artikel hasil penelitian yang terkait dengan topik penelitian. Menurut Siregar dan Harahap (2019) menyatakan bahwa analisis data dapat dilakukan dengan mengumpulkan sumber-sumber yang relevan dan terbaru untuk meringkas, menganalisis dan menarik sebuah kesimpulan dari hasil penelitian yang lain.

\section{HASIL PENELITIAN}

\section{Perkembangan Kreativitas Bagi Anak Usia Dini}

Pengembangan kreativitas anak merupakan kemampuan seseorang untuk berekpresi dan menemukan ide-ide baru. Menurut Fauziah (2013) menjelaskan bahwa kreativitas merupakan kemampuan seseorang untuk menghasilkan sesuatu yang baru, baik berupa gagasan maupun karya nyata yang diperoleh dari hasil imajinasi sendiri. Astuti dan Aziz (2019) menyatakan bahwa kreativitas selain menciptakan sesuatu yang baru, kreativitas juga melahirkan suatu solusi yang unik terhadap masalah-masalah yang dihadapai.

Fakhriyani (2016) menyatakan bahwa pengembangan kreativitas sangat penting dikembangkan pada anak usia dini karena usia dini merupakan golden age atau masa emas yang menjadi pondasi bagi perkembangan anak selanjutnya. Menurut Mulayati dan Sukmawijaya (2013) menyatakan bahwa kreativitas sangat penting dalam kehidupan anak karena kreativitas dapat menjadikan manusia lebih produktif, serta dapat meningkatkan kualitas hidup dan dapat mempermudah mencari jalan keluar dari masalah yang dihadapi. Oleh karena itu kreativitas mempunyai pengaruh penting dalam proses kehidupan manusia selanjutnya.

Pertumbuhan dan perkembangan anak dapat dikembangkan dan diperoleh melalui pendidikan dengan tujuan menumbuhkan dan mengembangkan sikap, prilaku, pengetahuan, kecerdasan, bahasa serta kreativitas pada anak. begitu juga 
J-SANAK: Jurnal Kajian Anak

(p-ISSN: 2686-5343 |e-ISSN: 2715-7989)

Vol. (2)(02), (Januari-Juni)(2021), (Halaman)(76-88)

DOI: https://doi.org/10.24127/j-sanak.v2i02.816

dengan kreativitas memiliki tujuan tertentu terhadap perkembangan anak. Menurut Rohani (2017) menjelaskan bahwa kreativitas bertujuan untuk merangsang kemampuan anak agar dapat berfikir kreatif dalam mengembangkan bakatnya untuk membuat kombinasi baru. Menurut Rahmat dan Sum (2017) menyatakan bahwa pengembangan kreativitas bertujuan untuk memberikan kesempatan kepada anak untuk mewujudkan atau mengekspresikan apa yang dirasakannya menurut caranya sendiri.

Anak yang kreatif dapat terlihat dari perilaku yang dilakukannya yaitu selalu aktif dalam segala hal. Anak bersifat unik dan memiliki karakteristik yang berbeda, begitu juga dengan kreativitas yang mereka miliki. Menurut Suyanto dalam Sit, dkk. (2016) adalah senang menjelajahi lingkungan, suka mengamati dan memegang segala sesuatu, memiliki rasa ingin tahu yang besar suka mengajukan pertanyaan, bersifat spontan dalam menyatakan pikiran dan perasaanya, suka bertualang, suka melakukan bereksperimen, jarang merasa bosan dan memiliki daya imajinasi yang tinggi.

Setiap aspek perkembangan yang dilalui anak pasti memiliki faktor pendukung dan penghambat, begitu juga dengan kreativitas. Adapun faktor pendukung kreativitas anak menurut Aisyah (2017) adalah memberikan dorongan kreatif kepadaa anak dengan memberikan waktu kesempatan kepada anak untuk menyendiri dalam mengembangkan imajinasinya serta menyediakan sarana dan lingkungan yang kondusif untuk dapat merangsang dalam menumbuhkan kreativitas anak. Sedangkan faktor penghambat kreativitas anak adalah kurangnya dorongan dan rangsangan dari orang tua, guru dan lingkungan dalam mengembangkan kreativitasnya (Sari, 2005)

Perkembangan kreativitas pada anak perlu adanya strategi yag digunakan dalam mengembangkan kreativitasnya. Menurut Fauziah (2013) menyatakan bahwa dalam kreativitas terdapat dimensi 4p yang saling berkaitann yaitu (pribadi, press, proses dan produk) dimana pribadi yang kreatif akan mendapatkan dorongan dari lingkungannya dan kemudian anak menjalani proses kreatif dengan melalui tahap-tahap persiapan yang akan membantu anak dalam menghasilkan sebuah produk kreatif. jadi daat disimpulkan bahwa pribadi, press, proces dan produk ialah kemampuan ide seseorang yang di proses sehingga menjadi suatu produk.

Ada beberapa teori yang mengemukakan tentang perkembangan kreativitas. Salah satunya teori psikoanalisis menurut Carl Jung dalam Sit, dkk (2016) menyatakan bahwa teori psikoanalisis memandang kreativitas sebagai hasil mengatasi suatu masalah, yang biasanya dimulai sejak dini. dimana pribadi kreatif di pandang sebagai seseorang yang pernah mempunyai pengelaman traumatis, yang dihadapi dengan memunculkan gagasan-gagasan yang disadari dan tidak disadari bercampur menjadi pemecahan inovatif kreatif. Kemampuan untuk menghasilkan suatu produk kreatif sangat di pengaruhi oleh pengalaman dan 
J-SANAK: Jurnal Kajian Anak

(p-ISSN: 2686-5343 |e-ISSN: 2715-7989)

Vol. (2)(02), (Januari-Juni)(2021), (Halaman)(76-88)

DOI: https://doi.org/10.24127/j-sanak.v2i02.816

keterampilan yanag akan dimiliki anak sebelumnya, maka anak harus diberikan pengelaman dan pengetahuan yang sesuai dengan kebutuhannya agar anak berusaha memuaskan kebutuhan psikologisnya.

Kreativitas anak akan berkembang sangat baik, ketika anak mampu mengembangkan suatu karya bersifat nyata. Menurut Rohani (2017) menyatakan bahwa anak yang dikatakan kreatif apabila anak mampu menghasilkan suatu produk, dengan memberikan kegiatan permainan yang menarik perhatian ank seperti aktivitas dalam membeuat hasil karya yang dapat membantu anak untuk mengembangkan imajinasnia. Menurut Aisyah (2017) menyatakan bahwa pengembangan kreativitas anak melaui hasil karya penting dalam aspek perkembangannya, setiap anak akan menggunakan imajinasinya dalam menghasilkan suatu produk sesuai dengan khayalannya. Hasil karya anak dapat dieroleh melalui aktivitas yang sedang dilakukan anak dengan memberikan kesempatan kepada anak untuk menghasilkan produk yang belum pernah ditemuinya.

\section{Kegiatan Membentuk Tanah Liat Bagi Anak Usia Dini}

Membentuk dimaksudkan sebagai mengubah, membangun dan mengwujudkan. Menurut Nurfajria (2017) menyatakan bahwa membentuk adalah kegiatan seni rupa tiga dimensi yang dimanfaatkan untuk menghasilkan suatu karya seni fungsional maupun karya seni murni. Menurut Pamilia, Yuhasriati dan Rosmiati (2019) menyatakan bahwa perkembangan kreativitas anak dapat dikembangkan dengan kegiatan mebentuk sesuai dengan usia anak dan salah satu kegiatan membentuk yang dapat dilakukan anak yaitu dengan menggunakan tanah liat.

Kegiatan membentuk adalah membuat bentuk. Kegiatan membentuk dapat diperlukan untuk perkembangan anak sepenuhnya. Menurut Pamadhi dan Sukardi (2018) menyatakan bahwa manfaat kegiatan membentuk pada anak yaitu untuk mengenalkan kepada anak benda alam yang ada di lingkungan dan mengembangkan fungsi oatak dan rasa pada anak serta mengembangkan keterampilan anak dalam menumbukan kecakapan hidupya. Menurut penelitian Nurfajria (2017) menyatakan bahwa membentuk dapat dijadika sebagai kegiatan yang dapat mengembangkan fungsi otak dan rasa pada anak untuk membentuk suatu karya.

Ada bebrapa teknik yang dapat dilakukan dalam mebentuk. Menurut Sumanto (2005) menyatakan bahwa teknik-teknik yang dilakukan dalam membentuk tanah liat yaitu membutsir, memahat, mengecor, atau menuang dan menyusun. Membutsir adalah teknik membentuk dengan bahan lunak salah satunya tanh liat yang dilakukan dengan cara membentuk langsung dengan menggunakan tangan sendiri maupun dengan alat. Memahat yaitu teknik membentuk dengan 
J-SANAK: Jurnal Kajian Anak

(p-ISSN: 2686-5343 |e-ISSN: 2715-7989)

Vol. (2)(02), (Januari-Juni)(2021), (Halaman)(76-88)

DOI: https://doi.org/10.24127/j-sanak.v2i02.816

menggunakan bahan bersifat keras yang dilakukan dengan menggunakan alat pahat. Mengecor atau menuang yaitu teknik membentuk dengan menggunkan bahan cair yang dilakukan dengan menggunakan alat cetak. Menyususn yaitu teknik yang dilaukan dengan menggunakan bahan alam yag dilakukan dengan cara menyususn bahan menjadi suatu karya seni yang unik.

Supriatna (2018) menyatakan bahwa tanah liat adalah media bahan alam yang berasal dari pelapukan kaerak bumi yang teridiri dari batuan feldspatik yang terdiri dari batuan granit dan batuan beku. Tanah liat juga merupakan media yang cukup kreatif dan mengandung unsur kreatif bagi pembelajaran anak. Menurut Nurfajria (2017) menyatakan bahwa tanh liat merupakan benda alam yang meiliki sifat fleksibel atau mudah diatur dan suatu kegiatan yang dapat dilakukan anak untuk membentuk apa yang diinginkan.

Menurut Maisarah, Mahmud dan Saugi (2020) menyatakan bahwa kegiatan membentuk tanah liat merupakan salah satu kegiatan yang menyenangkan dan dapat menarik perhatian anak dalam membuatnya serta tidak membosankan bagi anak. Menurut Fauziah ( 2013) menyatakan bahwa penggunaan media bahan alam merupakan suatu media yang digunakan anak untuk berinteraksi dengan menggunakan bahan alam yang disektar anak dan menjadikan media belajar yang konkreat bagi anak. Melalui media bahan alam dapat memberikan contoh yang nyata selama melaksankan pembelajaran.

Kegiatan dalam membantuk tanah liat memiliki tujuan dan manfaat bagi anak. Menurut Wahyuni (2019) menyatakan bahwa tanah liat bertujuan untuk melatih anak untuk mengembangkan imajinasi dan kreativitasnya dalam menciptakan suatu karya, dengan menjelaskan kepada anak bagaimana cara membentuk tanh liat. sedangkan manfaat tanah liat menurut Rahayu dan Khaironi (2018) adalah sebagai media yang dapat mengembangkan berbagai kemampuan aspek perkembangan anak menghasilakn suatu karya yang bernilai kreatif.

\section{Analisis Kegiatan Membentuk Tanh Liat Terhadap Perkembangan Kreativitas Anak Usia Dini}

Berdasarkan konsep perkembangan kreativitas anak usia dini melalui kegiatan membentuk tanh liat, maka analisis penelitian dari berbagai artikel yang terdapat pada jurnal, buku dan hasil penelitian yang sudah ada sebelumnya di temukan hasil sebagaai berikut:

Pertama, kegiatan membentuk tanah liat merupkan salah satu cara yang dapat diterapkan sebagai kegiatan belajar sambilbermain untuk meningkatkan kreativitas pada anak. Kegiatannya pun mudah untuk dimengerti dan dilakukan oleh anak. Menurut Putro (2016) mnyatakan bahwa kreativitas anak terlihat ketika bermain. Bermain merupakan sumber utama dalam menumbuhkan perkembangan anak dalam mengenal diri dan lingkungannya dan anak memiliki kesempatan 
J-SANAK: Jurnal Kajian Anak

(p-ISSN: 2686-5343 |e-ISSN: 2715-7989)

Vol. (2)(02), (Januari-Juni)(2021), (Halaman)(76-88)

DOI: https://doi.org/10.24127/j-sanak.v2i02.816

untuk mengekspresikan sesuatu yang ia rasakan dan pikirkan. Menurut Fauziddin (2016) menyatakan bahwa cara efektif dalam mengembangkan kreatif anak adalah dengan bermain, karena dengan bermain dapat membantu anak untuk mengekspresikan dirinya untuk mendorong kreativitasnya. Menurut Maisarah, Mahmud dan Saugi (2020) menyatakan bahwa bermain akan memberikan kesempatan kepada anak untuk mengembangkan kemampuan berfikirnya dalam membuat bentuk dari tanah liat, sebagai upaya untuk mengembangkan kreatifnya untuk menemukan sesuatu yang baru.

Kedua, kegiatan membentuk tanah liat merupakan kegiatan yang menggunakan media sederhana, kreatif dan menarik untuk anak. Karakteristik media seperti ini sesuai dengan kebutuhan anak dan menjadikan suatu kegiatan yang dapat memotivasi belajar anak. Menurut Khasanah (2019) menyatakan bahwa anak usia dini merupakan sosok individu yang unik dan memiliki rasa ingin tahu tinggi terhadap lingkungannya dengan cara mengekspor, memegang, meneliti dan melihat benda yang ada di sekitarnya.Kegiatan ini sederhana untuk anak karena bahan yang digunakan sudah dikenal oleh anak sebelumnya.Sehingga dengan menggunakan kegiatan membentuk tanah liat sebagai kegiatan dalam mengembangkan kreativitas akan dapat menarik perhatian anak dalam menciptakan suatu karya dengan cara mencoba dan mempraktikkan langsung media tersebut dengan keinginannya.

Ketiga, penggunaan media tanah liat dapat mengembangkan kreativitas pada anak usia dini. Menurut Sari (2005) menyatakan bahwa banyak hal dapat meningkatankreativitasanak seperti memberikan dorongan kreatif dan waktu untuk bermain. Menurut Hardiyanti (2020) meyatakan bahwa bermain dapat membantu kebutuhan anak untuk mengembangkan proses pertumbuhan dan perkembangannya, melaui bermain anak dapat belajar dan menjelajahi dunia sekitarnya dalam mengembangjan imanjinasi dan kreatifnya. Menurut Kurnia (2012) menyatakan bahwa kreativitas adalah kemamuan seseorang untuk menciptakan sesuatu yang baru atau kombinasi baru dengan unsur yang telah ada sebelumnya sehingga menjadi sesuatu yang bermakna dan bermanfaat. Oleh karena itu kreativitas penting untuk distimulasi sejak dini, karena dengan kegiatan membentuk tanah liat anak dapat mengembangkan kreativitasnya untuk menghasilkan sesuatu karya yang berbeda dari karya yang ada sebelumnya (Sagala \& kamtini, 2019).

Keempat, kegiatan membentuk tanah liat dapat melatih dan meningkatkan daya imajinasi anak dalam mengembangkan kreativitas. Anak usia dini adalah anak yang kaya akan imajinasi. Menurut Mushonifah (2016) menyataakan bahwa pengembangan kreativitas yang dimiliki oleh anak dapat berupa imajinasi yang mempunyai kebutuhan untuk menyatakan pikiran dan perasaanya. Menurut Sularsih (2021) menyatakan bahwa bermain menggunakan tanah liat dapat menuangkan imajinasinya untuk membuat berbagai macam bentuk sesuai dengan 
J-SANAK: Jurnal Kajian Anak

(p-ISSN: 2686-5343 |e-ISSN: 2715-7989)

Vol. (2)(02), (Januari-Juni)(2021), (Halaman)(76-88)

DOI: https://doi.org/10.24127/j-sanak.v2i02.816

keinginannya. Menurut Rahayu dan Khaironi (2018) menyatakan bahwa tanah iat merupakan suatu media yang dapat meningkatkan imajinasi anak dalam mengembangkan kreatifnya, dimana anak dapat diberi kebebasan dalam menciptakan bentuk prakarya yang kreatif sesuai keinginannya. Kegiatan membentuk dapat mengasah kreativitas anak untuk berimajinasi. Sebelum anak melakukan kegiatan membentuk dengan tanah liat, anak akan memikirkan terlebih dahulu bentuk seperti apa yang akan dibuatnya tersebut sehingga menghasilkan suatu karrya yang bernilai kreatif. Kegiatan bermain tanah liatsangat baik dilakukan untuk meningkatkan imajinasi dan kreativitas anak agar mendapatkan hasil yang diinginkan (Wahyuni, 2019).

Kelima, kegiatan membentuk tanah liat dapat mestimulasi perkembangan anak. Stimulasi yang diberikan kepada anak akan berperan penting terhadap perkembangan anak selanjutnya. Oleh karena itu orang tua atau pendidik harus memberikan stimulasi yang tepat untuk mengoptimalkan tumbuh kembang anak agar anak menjadi kreatif. Menurut Mulyati dan Sukmawijaya (2013) menyatakan bahwa kreativitas sangat penting untuk dikembangkan kepada anak sejak mulai dari usia dini, kareana kreativitas sangat berpengaruh sekali terhadap perkembangan aspek-aspek perkembangan. Menurut Rahayu dan Khaironi (2018) menyatakan bahwa kegiatan membentuk tanah liat sangat bermanfaat terhadap perkembangan kreativitas anak dan juga dapat mengembangkan aspek lainnya, seperti 1) meatih motorik halus anak, membuat berbagai macam bentuk tanh liat dengan teknik bebas, teknik pilin dan teknik lempeng; 2) melatih kemampuan kognitif pada anak dalam berimajinasi; 3) melatih kemampuan bahasa anak, pada saat anak berbicara dalam menemukan ide dan mengkomunikasikan hasil karyanya; 4) melatih kemampuan sosial emosi pada anak, seperti memupuk kemandirian, meningkatkan percaya diri dan dapat menumbuhkan rasa tanggup jawab pada anak.

Keenam, kegiatan membentuk tanh liat dapat mengasah perkembangan kreativitas anak dalam membentuk suatu karya yang baru dengan cara membentuk tanah liat sesuai keinginan anak. Menurut Rahayu dan Khaironi (2018) menyatakan bahwa kegiatan membentuk dengan tanah liat dapat memberikan kebebasan kepada anak untuk menciptakan hasil karyanya sendiri sehingga menghasilakn produk yang nyata sesuai dengan apa yang dikhayalkannya. Berkarya dapat mengembangkan kreativitas pada anak dan berkreasi akan dapat membantu anak untuk berfikri kreatif dalam menghasilkan dan menyelesaikan suatu masalah. Menurut Debeturu dan Wijayaningsih (2019) menyatakan bahwa kreativitas harus diberikan kepada anak semenjak berusia dini, karena dengan kreativitas akan dapat membantu anak untuk berimajinasi untuk menemukan ideide baru yang akan membantu anak dalam menghasilkan dan membuat sesuatu hal yang baru. Bagi anak berkreasi akan menjadi kesenangan tersendiri untuk anak dalam mengembangkan ide yang mereka miliki. Anak yang kreatif adalah anak 
J-SANAK: Jurnal Kajian Anak

(p-ISSN: 2686-5343 |e-ISSN: 2715-7989)

Vol. (2)(02), (Januari-Juni)(2021), (Halaman)(76-88)

DOI: https://doi.org/10.24127/j-sanak.v2i02.816

yang apabila mampu menghasilkan suatu produk secara kreatif dan tidak tergantung dengan orang lain (Rohani, 2017)

Ketujuh, penggunaan media tanah liat adalah sebagai bahan yang mudah didapat, tidak berbahaya dan mudah dibentuk oleh anak, sehingga anak dapat secara bebas dalam memainkannya. Menurut Rahayu dan Mayar (2019) menyatakan bahwa tanah liat termasuk media bahan alam yang sederhana, mudah didapat dan dibentuk serta tidak berbahaya digunakan oleh anak dan kegiatan membentuk tanah liat merupakan susatu proses pembelajaran yang dapat memberikan kebebasan kepada anak untuk membuat dan menciptakan suatu karya yang diinginkan. Menurut Supriatna (2018) menyatakan bahwa penggunaan media pembelajaran sngat dianjurkan untuk dapat mempertinggi kualitas anak dalam pembelajaran salah satunya media tanah liat yang dapat digunakan sebagai media yang menghasilkan suatu karya tiga dimensi.

Berdasarkan hasil dan pembahasan penelitian, maka dapat disimpulkan bahwa perkembangan kreativitas anak dapat dikembangkan melalui kegiatan membentuk dengan tanah liat. Kegiatan membentuk tanah liat tidak hanya mengembangkan kreativitas dan imajinasi anak, tetapi juga dapat mengembangkan kemampuan aspek perkembangan lainnya seperti melatih otorik halus anak melalui memegang, memijat dan meremas, malatih kemampuan kognitif anak dalam berimajinasi, melatih bahasa anak dalam mengkomunikasikan hasil karyanya serta melatih sosial emosi pada anak dengan memupuk kemandirian dan meningkatkan percaya diri pada anak.

\section{KESIMPULAN}

Berdasarkan hasil penelitian dan pembahasan, maka dapat disimpulkan bahwa perkembangan kreativitas anak dapat dikembangkan melalui kegiatan membentuk tanah liat. Hasil penelitian dapat didasarkan atas temuan keunggulan yang berkaitan dengan kegiatan kegiatan membentuk tanah liat. Adapun keunggulan yang dimaksud yaitu dapat meningkatkan imajinasi anak dalam mengembangkan kreativitas, memberikan kesempatan kepada anak untuk menciptakan suatu hasil karya baru, menstimulasi perkembangan anak dan media yang digunakan sederhana dan mudah digunakan untuk bermain.

\section{E. DAFTAR PUSTAKA}

Astuti, Ria, dan Thorik Aziz. 2019. Integrasi Pengembangan Kreativitas Anak Usia Dini di TK Kanisius Sorowajan Yogyakarta. Jurnal Obsesi: Jurnal Pendidikan Anak Usia Dini. Vol. 3 No. 2

Aisyah, Dewi Siti. 2017. Strategi Pengembangan Kreativitas Anak Usia Dini dalam Menciptakan Produk (Hasta Karya)(Studi Kualitatif di PAUD Harapan Kecamatan Cilamaya Kulon Kabupaten Karawang). Jurnal Pendidikan Islam Rabbani. Vol. 1 No. 1 
J-SANAK: Jurnal Kajian Anak

(p-ISSN: 2686-5343 |e-ISSN: 2715-7989)

Vol. (2)(02), (Januari-Juni)(2021), (Halaman)(76-88)

DOI: https://doi.org/10.24127/j-sanak.v2i02.816

Debeturu, Belandina dan Wijayaningsih, Lanny. 2019. Meningkatkan Kreativitas Anak Usia 5-6 Tahun melalui Media Magic Puffer Ball. Jurnal Obsesi: Jurnal Pendidikan Anak Usia Dini. Vol. 3 No.1

Fadillah, M. 2018. Beramain dan Permainan Anak Usia Dini. Jakarta: Kencana

Fauziah, Nadia. 2013. Penggunaan Media Bahan Alam untuk Meningkatkan Kreativitas Anak. Jurnal Ilmiah Visi. Vol. 8 No. 1

Fakhriyani, Diana Vidya. 2016. Pengembangan Kreativitas Anak Usia Dini. Wacana Didaktika Jurnal Pemikiran Peneitian Pendidikan dan Sains. Vol. 4 No. 2

Fauziddin, Mohammad. 2016. Penerapan Belajar Melalui Bermain Balok Unit untuk Meningkatkan Kreativitas Anak Usia Dini. Jurnal Curricula. Vol. 1 No. 3

Hardiyanti, Widya Dwi. 2020. Aplikasi Bermain Berdasarkan Kegiatan Seni Lukis untuk Stimulasi Kreativitas Anak Usia 5-6 Tahun. Jurnal Pendidikan Anak. Vol. 9 No. 2

Khasanah, Iis. 2017. Upaya Peningkatan Kemampuan Berhitung Permulaan Anak Usia 3-4 Tahun Melalui Permainan Kubus Angka. Jurnal Islamic Early Childhood Education. Vol. 2 No. 1

Kurnia, Rita. 2012. Konsepsi Bermain dalam Menumbuhkan Kreativitas Pada Anak Usia Dini. Jurnal Educhild: Pendidikan dan Sosial. Vol. 1 No. 1

Maisarah, Ayu., Eka Mahmud, Muchammad dan Saugi, Wildan. 2020. Meningkatkan Kreativitas Anak Melalui Metode Bermain Platisin Tanah Liat. Journal For Early Childhood Education Research. Vol. 1 No. 1

Madyawati, Lilis. 2016. Strategi Perkembangan Bahasa Pada Anak. Jakarta: Kencana

Maulana, Ihsan., dan Mayar, Farida. 2019. Pengembangkan Kreativitas Anak Usia Dini Di Era Revolusi 4.0. Jurnal Pendidikan Tambusai. Vol. 3 No. 3

Miranda, Dian. 2018. Pengembangan Buku Cerita Berbasis Pendidikan Karakter Untuk Meningkatkan Kreativitas AUD. Jurnal Visi Ilmu Pendidikan. Vol.10 No.1

Mushonifah, Leni. 2016. Meningkatkan Kreativitas Anak Usia Dini Melalui Bermain Plastisin Di RA Khoirul Ummah Leni. Journal of Chemical Information and Modeling. Vol. 2 No. 1

Mulyati, Sri., dan Amalia Aqmarina Sukmawijaya. 2013. Meningkatkan Kreativitas Pada Anak. Asian Journal of Innovation and Entrepreneurship. Vol. 2 No. 2

Nurfajria, Lin Samslah. 2017. Meningkatkan Kemampuan Motorik Halus Melalui Kegiatan Membentuk Menggunakan Media Tanah Liat Di Kelompok B Tk Ar-Rofi (Penelitian Tindakan Kelas Di Kelompok B Tk Ar-Rofi Bantargebang-Bekasi). Jurnal Peneitian dan Pengembangan Anak Usia Dini. Vol. 4 No.1

Pamilia, Rina., Yuhasriati, dan Rosmiati. 2019. Perkembangan Kreativitas Anak Melalui Kegiatan Membentuk Di Tk Bungong Seuleupoek Banda Aceh. Jurnal Ilmiah Mahasiswa Pendidikan Guru Anak Usia Dini. Vol. 4 No. 3

Pamadhi, Hajar dan Evan Sukardi. 2018. Seni Keterampilan Anak. Tanggerang Selatan: Universitas Terbuka 
J-SANAK: Jurnal Kajian Anak

(p-ISSN: 2686-5343 |e-ISSN: 2715-7989)

Vol. (2)(02), (Januari-Juni)(2021), (Halaman)(76-88)

DOI: https://doi.org/10.24127/j-sanak.v2i02.816

Putro, Khamim Zarkasih. 2016. Mengembangkan Kreativitas Anak Melalui Bermain. Aplikasia: Jurnal Aplikasi Ilmu-ilmu Agama. Vol. 16 No. 1

Rachmawati, Yeni dan Euis Kurniati. 2017. Strategi Pengembengan Kreativitas Pada Anak Usia Taman Kanak-Kanak. Jakarta : Kencana.

Rahayu, Dwi Isti dan Khaironi Mulianah. 2018. Kreativitas Anak dan Clay Tanah Liat. Jurnal Pendidikan Indonesia. Vol.1 No. 1

Rahayu, Intan, and Farida Mayar. 2019. Pengaruh Tanah Liat Terhadap Kreativitas Anak Usia Dini Di Taman Kanak-Kanak Aisyiyah 29 Tanjung Aur Padang. Al-Hikmah: Indonesian Journal of Early Childhood Islamic Education. Vol. 3 No. 1

Rahmat, Stephanus Turibius, and Theresia Alviani Sum. 2017. Mengembangkan Kreativitas Anak.Jurnal Pendidikan dan Kebudayaan Missio. Vol. 9 No. 2

Rohani. 2017. Meningkatkan Kerativitas Anak Usia Dini Melalui Media Bahan Bekas. Jurnal Rauda. Vol. 5 No. 2

Sagala, Remida dan Kamtini. 2019. Pengaruh Kegiatan Mencetak Terhadap Kreativitas Anak Kelompok B Di TK Assisi Medan Tahun Ajaran 2018/2019. Jurnal Usia Dini. Vol. 5 No.1

Sari, Sriti Mayang. 2005. Peran Ruang Dalam Menunjang Kreativitas Anak. Jurnal Desain Interior Fakultas Seni Dan Desain. Vol. 3 No. 1

Sit, Masganti. 2016. Pengembangan Kreativitas Anak Usia Dini Teori dan Praktik. Medan: Perdana Publishing.

Siregar dan Harahap. 2019. Strategi dan Teknik Penulisan Karya Tulis Ilmiah dan Publikasi. Yogyakarta: Cv Budi Utama

Suryana, Dadan. 2013. Pendidikan Anak Usia Dini (Teori dan Pratek Pembelajaran). Padang: Unp Press

Supriatna, Milla Anggamala. 2018. Penggunaan Tanah Liat Sebagai Media Pembelajaran Pengenalan Bentuk Dasar Tiga Dimensi Bagi Pendidikan Anak Usia Dini. Cakrawala Dini: Jurnal Pendidikan Anak Usia Dini. Vol 5 No. 1

Sularsih, Tri.. 2021. Meningkatkan Keterampilan Motorik Halus Menggunakan Media Tanah Liat Pada Anak Kelompok A Tk Tunas Karya Ii Desa Kayen Kecamatan Pacitan Kabupaten Pacitan Tahun 2019. Jurnal Visioner: Hasil Penelitian Pendidikan Dasar dan Anak Usia Dini. Vol. 1 No. 1

Sumanto. 2005. Pengembangan Kreativitas Seni Rupa Anak TK. Jakarta: Dapartemen Pendidikan Nasional

Sulastianto, Harry., dkk. 2006. Seni Budaya Untuk Kelas XII Sekolah Menengah Atas. Bandung: Grafindo.

Wahyuni, Ana. 2019. Melalui Metode Bermain Tanah Liat Dapat Meningkatkan Imajinasi dan Kreativitas Anak Kelompok B1 Tk Babussaadah Sabang. Jurnal Ekonomi, Pendidikan, Dan Sains. Vol. 3 No. 2

Zed, Mustika. 2008. Metode Penelitian Kepustakaan. Jakarta: Yayasan Obor Indonesia 